\title{
Diagnostic uncertainty and epistemologic humility
}

\author{
Andrew Kelly ${ }^{1,2}$ - Richard S. Panush ${ }^{1,2}$
}

Received: 3 April 2017 / Accepted: 10 April 2017 / Published online: 22 April 2017

(C) International League of Associations for Rheumatology (ILAR) 2017

Keywords Diagnosis $\cdot$ Epistemology $\cdot$ Labeling · Uncertainty

"The essence of medicine is the reduction of uncertainty." (Baldhius, as quoted by J Claude Bennett, MD \{cited in [1]\})

How often have we encountered the patient labeled as having both rheumatoid arthritis and systemic lupus erythematosus? Or, with arthralgias and a positive antinuclear antibody (ANA) said to have an "overlap syndrome"? Recently, it was someone with erosive arthritis, inflammatory myopathy, alopecia, Raynaud phenomenon, urinary red blood cell casts, ANA 1:640 with elevated anti-DS-DNA, and high rheumatoid factor (RF) titer and anti-cyclic citrullinated protein (CCP) antibody levels who was called "mixed connective tissue disease". What are the correct, or best, diagnoses for these patients? Why does it matter?

We suggest that we do not know the diagnoses of these particular illustrative patients with confidence. We believe that we should not attempt to assign clear diagnoses in the face of uncertainty. Doing so at least risks suboptimal care and can lead to harm. We think we should accept epistemological uncertainty, however discomfiting, when confronted by such patients and not attempt to confer ill-fitting diagnostic labels.

Epistemology - that branch of philosophy which examines the theory of knowledge - offers a pertinent perspective. In

Richard S. Panush

panush@usc.edu

1 Divisions of Rheumatology, Department of Medicine, Keck School of Medicine, University of Southern California, Los Angeles, CA, USA

2 Division of Rheumatology, Department of Medicine, LAC+USC Medical Center, Los Angeles, CA, USA part, it addresses relationships between beliefs and truths. For example, an individual may have a particular belief but it may not be true. When it can be known to be true, a belief is termed knowledge [2]. In medicine, we fervently pursue "truth" so as to understand disease sufficiently to cure or, at least manage, illness. In this process many beliefs, or hypotheses, are created but they are not necessarily truths. We seek an elusive certainty. Indeed, "the essence of medicine is the reduction of uncertainty".

Our introductory clinical examples reflect a common dilemma in rheumatology, indeed in medicine - deciding how to label those patients whose clinical features defy simple diagnosis according to contemporary understanding. Some patients have manifestations of more than a single nosologic entity while others do not display findings which would satisfy diagnostic (really "classification") criteria for any of the currently recognized rheumatic disorders. And even our diagnostic/classification criteria are inadequate. Who still thinks, for example, that rheumatoid arthritis or systemic lupus erythematosus is a single homogeneous entity [3]? We believe these predicaments are not uncommon and are not always fully appreciated. Failure to recognize such instances can have adverse consequences.

As much as $25 \%$ of rheumatic disease patients with systemic symptoms cannot be diagnosed definitively [4-6]. Furthermore, the majority of these patients will remain undiagnosed during 5 to 10 years of follow-up [6-9]. Historically, many such patients were described as having "collagen" or "connective tissue" diseases since they shared similar clinical and pathologic features of widespread inflammation [6-9]. Now, these patients are generally considered to have "diffuse" or "undifferentiated" (or sometimes "early undifferentiated") systemic rheumatic diseases (a term we prefer to "connective tissue diseases" or "collagen vascular diseases", as these are not really disorders of connective tissue or collagen as 
originally conceived) [6,10-15]. Other patients with rheumatic diseases have systemic features that overlap two or more specific recognized entities and also cannot be diagnosed definitively $[5,6,16-18]$. And still, others evolve through several different reasonable diagnoses [5].

We urge caution in assigning a diagnosis, or even offering several diagnoses (e.g., rheumatoid arthritis and systemic lupus erythematosus) for patients with symptoms of rheumatic diseases who do not meet currently accepted criteria $[4,18$, 19]. Assigning diagnostic labels to patients implies certainty or confidence in pathogenesis, prognosis, therapeutic implications, and outcomes, and should not be based either on only laboratory or serologic abnormalities or on isolated clinical features. Rendering a diagnosis in such circumstances may inappropriately circumscribe the physicians' thinking, which can lead to inappropriate management, harm, and even adverse legal consequences. In such circumstances of diagnostic uncertainty, we refer to these patients as having "undifferentiated systemic rheumatic disease." An example of this was the controversy about silicone breast implants and the purported link with rheumatic disease in the 1970s to 1990s [20]. This was first reported in Japan, then sensationalized in American media, and termed "silicone breast implant-related rheumatic syndrome", reflecting belief in the validity of the newly identified association. Reaction to this led to removal of silicone implants from the market and prohibitively expensive plaintiff suits against manufacturers, with confounding industrial and societal consequences [20]. When the phenomenon was eventually examined in an objective scientific manner, no link was demonstrated between silicone breast implants and rheumatic disease [20,21].

Diagnostic uncertainty of course is not unique to rheumatology. Patients with "medically unexplained symptoms" (MUS) are not infrequently encountered. More than $50 \%$ of outpatients with physical complaints do not have a diagnosable medical condition [22-25]. These have been called "somatization" and later "somatic symptoms and related disorders" [26-30]. These patients may have a variety of syndromes, which have been termed "fibromyalgia", "systemic exertion intolerance disease", "premenstrual dysphoric disorder", "temporomandibular joint disorder", and "idiopathic environmental intolerance" [31-41]. Some of these patients with seemingly unexplained symptoms may eventually evolve to a diagnosable disorder, and some of these may be patients with diseases yet to be identified. A striking example of the latter comes from the story of Susannah Cahalan, a New York Post journalist and author, who became violent and delusional and was believed initially to have a psychiatric illness; thoughtful neuropsychological examination led to a diagnosis of a new form of autoimmune encephalitis, anti-NMDA disease [42]. "Navajo arthritis" became a spondyloarthropathy [43] and "eosinophilic myopathy" was found due to 1-tryptophan ingestion [44], to cite additional examples. What was "pseudogout" before McCarty identified the pyrophosphate crystals [45]? The "MonoMAC" syndrome before it was recognized [46]? And others like these? And what of those patients who evolve/transform through different "diagnostic" entities? What else will we re-label in the coming years as our understandings become more sophisticated?

More specific to rheumatology, and to unexplained rheumatic symptoms, is the example of the evolution of fibromyalgia. Originating with the term "fibrositis" in the 1950s, it was described as musculoskeletal pain, stiffness, and soreness, not as a disease entity but as a syndrome brought about by a variety of widely separate conditions [47]. This definition would remain until the 1980s when, in an attempt to broaden the indications for cyclobenzaprine, Merck, Sharp, and Dohme, Inc. underwrote a symposium and the formation of a committee that replaced the term fibrositis with fibromyalgia as defined by the American College of Rheumatology 1990 criteria [47]. The new criteria legitimized patients with chronic widespread pain without demonstrable disease. However, as Hadler argued, diagnostic labeling can have powerful and unrecognized effects on the patient $[47,48]$. Most notable are those on patient identity, transforming someone from a healthy person with many life options into a long-term patient with a life dominated and limited by disease. Too, there are the insurance (and disability) implications of labeling patients with uncertain diagnoses [47]. Thus, there is inherent danger in the medicalization of widespread chronic pain manifested in the social construct of fibromyalgia. It is in part for these reasons that we sometimes use the old-fashioned term "rheumatism" or even "rheumatologically unexplained symptoms" (RUS) for patients whose rheumatologic/musculoskeletal symptoms we cannot adequately explain or diagnose.

There are additional implications of rendering a diagnosis. A diagnosis implies a level of certainty in the decision to label a condition and in the pathophysiologic process. Incorrect diagnostic labeling not only can lead to inappropriate courses of action but also impair our ability to critically re-appraise our beliefs.

Medicine is considerably less evidence-based than we sometimes think [49] and we understand, really understand, fewer conditions than we presume [50]. Diagnostic and epistemologic humility should be a more common default position than is usually taken. We need to be comfortable with the uncomfortable. It better serves our science and art, and our patients. While uncertainty can be distressing, the alternative is indeed more perilous.

"Uncertainty is an uncomfortable position. But certainty is an absurd one." (Voltaire)

\section{Compliance with ethical standards}

Disclosures None. 


\section{References}

1. Perret D, Chang EY, Pang W, Shinada S, Panush RS (2013) Reflecting on pain management for patients with osteoarthritis and other rheumatic disorders: there's more to pain management than managing pain. Pain Management 2(4):295-301

2. Bengson J, Moffett MA (2012) Knowing how: essays on knowledge, mind, and action. Oxford University Press

3. Arend WP, Firestein GS (2012) Pre-rheumatoid arthritis: predisposition and transition to clinical synovitis. Nature Rev Rheum 8:573586. doi:10.1038/nrrheum.2012.134

4. Dubois EL, Wallace DJ (1987) Dubois' Lupus Erythematosus. Lea and Febiger, Philadelphia

5. Cervera R, Khamashta MA, Hughes GR (1990) "Overlap" syndromes. Ann Rheum Dis 49:947-948

6. Panush RS, Kramer N, Rosenstein ED (2016) Undifferentiated systemic rheumatic (connective tissue) diseases and overlap syndromes. Up-To-Date In Medicine. http://www.uptodate.com/ contents/undifferentiated-systemic-rheumatic-connective-tissuediseases-and-overlap-syndromes. Accessed 28 March 2017

7. Klemperer P (1961) The concept of collagen diseases in medicine. Amer Rev Respir Dis 83:331-339

8. Klemperer P (1962) The concept of connective-tissue disease. Circulation 25:869-871

9. Doria A, Mosca M, Gambari PF, Bombardieri S (2005) Defining unclassifiable connective tissue diseases: incomplete, undifferentiated, or both? J Rheumatol 32:213-215

10. LeRoy EC, Maricq HR, Kahaleh MB (1980) Undifferentiated connective tissue syndromes. Arthritis Rheum 23:341-343

11. Kallenberg CG (1993) Overlapping syndromes, undifferentiated connective tissue disease, and other fibrosing conditions. Curr Opin Rheumatol 5:809-815

12. Alarcon GS, Williams GV, Singer JZ, Steen VD, Clegg DO, Paulus HE, Billingsley LM, Luggen ME, Polisson RP, Wilkens RF et al (1991) Early undifferentiated connective tissue disease. I. Early clinical manifestations in a large cohort of patients with undifferentiated connective tissue diseases compared with cohorts of well established connective tissue disease. J Rheumatol 18:1332-1339

13. Clegg DO, Williams HJ, Singer JZ, Steen VD, Schlegel S, Ziminski C, Alarcon GS, Luggen ME, Polisson RP, Wilkens RF et al (1991) Early undifferentiated connective tissue disease. II. The frequency of circulating antinuclear antibodies in patients with early rheumatic diseases. J Rheumatol 18:1340-1343

14. Bulpitt KJ, Clements PJ, Lachenbruch PA, Paulus HE, Peter JB, Agopian MS, Singer JZ, Steen VD, Clegg DO, Ziminski CM, Alarcon GS, Luggen ME, Polisson RP, Wilkens RF, Reading JC, Williams HJ, Ward JR (1993) Early undifferentiated connective tissue disease: III. Outcome and prognostic indicators in early scleroderma (systemic sclerosis). Ann Intern Med 118:602-609

15. Alarcon GS, Willkens RF, Ward JR, Clegg DO, Morgan JG, Ma KN, Singer JZ, Steen VD, Paulus HE, Lugger ME, Polisson RP, Ziminski CM, Yarboro C, Williams HJ (1996) Early undifferentiated connective tissue disease. IV. Musculoskeletal manifestations in a large cohort of patients with undifferentiated connective tissue diseases compared with cohorts of patients with well-established connective tissue diseases: follow-up analyses in patients with unexplained polyarthritis and patients with rheumatoid arthritis at baseline. Arthritis Rheum 39:403-414

16. Panush RS, Greer JM, Morshedian KK (1993) What is lupus? What is not lupus? Rheum Dis Clin N Am 19:223-234

17. Greer JM, Panush RS (1989) Incomplete lupus erythematosus. Arch Intern Med 149:2473-2476

18. Panush RS, Edwards NL, Longley S, Webster E (1988) "Rhupus" syndrome. Arch Intern Med 148:1633-1636
19. Wolfe F, Ross K, Hawley DJ, Robertss FK, Cathey MA (1993) The prognosis of rheumatoid arthritis and undifferentiated polyarthritis syndrome in the clinic: a study of 1141 patients. J Rheumatol 20: 2005-2009

20. Panush RS, Hadler NM, Hellman DB, Leroy EC (1999) Yearbook of rheumatology, arthritis and musculoskeletal disease. In: Panush RS (ed) Health sciences, epidemiology, and economics (sex, sensationalism, greed, politics, law, and junk science: the story of the silicone breast implant controversy). Mosby-Yearbook, Missouri, pp 1-5

21. Angell M (1997) Science on trial: the class of medical evidence and the law in the breast implant case. WW Norton, New York

22. Kroenke K, Mangelsdorr AD (1989) Common symptoms in ambulatory care: incidence, evaluation, therapy, and outcome. Am J Med 86:262-266

23. Kanton W, Ries RK, Kleinman A (1984) The prevalence of somatization in primary care. Compr Psychiatry 25:208-215

24. Kanton WJ, Walker EA (1998) Medically unexplained symptoms in primary care. J Clin Psychiatry 59(Suppl 20):15-21

25. Kroenke K, Price RK (1993) Symptoms in the community: prevalence, classification, and psychiatric comorbidity. Arch Intern Med 153:2474-2480

26. Creed F, Barsky A (2004) A systematic review of the epidemiology of somatisation disorder and hypochondriasis. J Psychosom Res 56: 391-408

27. World Health Organization (1992) The ICD-10 classification of mental and behavioral disorders: clinical descriptions and diagnostic guidelines. Geneva: World Health Organization. http://www. who.int/classifications/icd/en/bluebook.pdf Accessed on $28 \mathrm{Mar}$ 2017

28. American Psychiatric Association (2000) Diagnostic and statistical manual of mental disorders, fourth edition, text revision. American Psychiatric Association, Washington DC

29. American Psychiatric Association (2013) Diagnostic and statistical manual of mental disorders, fifth edition (DSM-5). American Psychiatric Association, Arlington

30. Yutzy SH, Parish BS (2008) Somatoform disorders. In: The American Psychiatric Publishing Textbook of Substance Abuse Treatment, 4th ed. American Psychiatric Publishing, Washington, DC

31. Goldenberg DL (1987) Fibromyalgia syndrome an emerging but controversial condition. JAMA 257:2782-2787

32. Clauw DJ (2014) Fibromyalgia: a clinical review. JAMA 311: $1547-1555$

33. Bennett RM (2009) Clinical manifestations and diagnosis of fibromyalgia. Rheum Dis Clin N Am 35:215-232

34. Institute of Medicine (2015) Beyond myalgic encephalomyelitis/ chronic fatigue syndrome: redefining an illness. The National Academies Press; 2015 http://www.iom.edu/mecfs. Accessed on 28 March 2017

35. Mehta NR, Forgione AG, Rosenbaum RS, Holmberg R (1984) "TMJ" triad of dysfunctions: a biologic basis of diagnosis and treatment. J Mass Dent Soc 33:173-176

36. Cooper BC, Kleinberg I (2007) Examination of a large patient population for the presence of symptoms and signs of temporomandibular disorders. Cranio 25:114-126

37. Hartlage SA, Freels S, Gorman N, Yonkers K (2012) Criteria for premenstrual dysphoric disorder: secondary analyses of relevant data sets. Arch Gen Psychiatry 69:300-305

38. Halbreich U, Backstrom T, Eriksson E et al (2007) Clinical diagnostic criteria for premenstrual syndrome and guidelines for their quantification for research studies. Gynecol Endocrinol 23:123130

39. Eis D, Helm D, Mühlinghaus T, Birkner N, Dietel A, Eikmann T, Gieler U, Herr C, Lacour M, Nowak D, Pedrosa Gil F, Podoll K, Renner B, Andreas Wiesmuller G, Worm M (2003) The German 
multicentre study on multiple chemical sensitivity (MCS). Int J Hyg Environ Health 211:658-681

40. Hausteiner C, Bornschein S, Bickel H et al (2003) Psychiatric morbidity and low self-attentiveness in patients with environmental illness. J Nerv Ment Dis 191:50-55

41. Das-Munshi J, Rubin GJ, Wessely S (2007) Multiple chemical sensitivities: review. Curr Opin Otolaryngol Head Neck Surg 15:274-280

42. Cahalan S (2012) Brain on fire: my month of madness. Penguin, NYC

43. Rate RG, Morse HG, Bonnell MD et al (1980) "Navajo arthritis" reconsidered: relationship to HLA-B27. Arthritis Rheum 23(11): 1299-1302

44. Martin RW, Duffy J, Engel AG, Lie JT, Bowles CA, Moyer TP, Gleich GJ (1990) The clinical spectrum of the eosinophilia-myalgia syndrome associated with L-tryptophan ingestion: clinical features in 20 patients and aspects of pathophysiology. Ann Intern Med 113(2):124-134
45. Kohn NN, Hughes RE, McCarty DJ Jr, Faires JS (1962) The significance of calcium phosphate crystals in the synovial fluid of arthritic patients: the "pseudogout syndrome". II. Identification of crystals. Ann Intern Med 56:738-745

46. Johnson JA, Yu SS, Elist M, Arkfeld D, Panush RS (2015) Rheumatologic manifestations of the "MonoMAC" syndrome. A systematic review. Clin Rheumatol 34(9):1643-1645

47. Hadler NM, Greenhalgh S (2004) Labeling woefulness: the social construction of fibromyalgia. Spine 30:1-4

48. Hadler NM (2003) "Fibromyalgia" and the medicalization of misery. J Rheumatol 30:1668-1669

49. Haynes B, Haines A (1998) Barriers and bridges to evidence based clinical practice. BMJ 317:273-276

50. Ioannidis JP (2005) Why most published research findings are false. PLoS Med 2:e124 